\title{
Relative Ability of Earnings Data and Cash Flow in Predicting Future Cash Flows
}

\author{
Nasrollah Takhtaei (Corresponding author) \\ Accounting Department, Dezful Branch, Islamic Azad University, Dezful, Iran \\ E-mail: nasrollah_takhtaei@yahoo.com \\ Hassan Karimi \\ Accounting Department, Dezful Branch, Islamic Azad University, Dezful, Iran \\ E-mail: hasankarimi73@yahoo.com
}

Received: April 29, 2013 Accepted: May 18, 2013 DOI: 10.5296/ijafr.v3i1.3803

\begin{abstract}
The purpose of this study is to examine earnings relative ability, operational cash flow, and two traditional measures of cash flows namely net earnings plus depreciation and operational working capital in predicting future cash flows. Also, the effect of company size on ability of predictive measures mentioned is examined in this study. The population examined includes accepted companies in Tehran Stock Exchange during period from 2005 to 2009. The results indicate that net earnings have more ability than operational cash flows and its traditional proxies in predicting the cash flows future. These findings are consistent with Financial Accounting Standards Board (FASB) claim based on earnings in preference on cash flows in predicting future cash flows.
\end{abstract}

Keywords: Operational cash flows, earnings, operational working capital, net earnings plus depreciation 


\section{Introduction}

Cash and cash flow for the company are as blood for the body and play an important role for users of accounting information in economic decision making. Although changes in cash could be measured by comparing its balance in two sequential balance sheet periods but, no one of them are able to state the main and complete reasons of these changes. Accordingly, in addition to these two mentioned financial statements, another financial statement is necessary that could report information regarding cash inflows and outflows within a financial period in a gross format. After 1980, companies have been required to prepare the statement of cash flow by accounting standard-setting bodies in all over the world. International requirements in the area of reporting cash could raise many issues in the area of the information usefulness of the cash flow among the academicians and legislators. The main point in this subject is that whether information as regards the statement of cash flows is able to present the information that there are not in the income based on the accruals. Here at the first, we present cash historical to offer cash and historical theory in the field of significance and usefulness of cash flow formation. Then we explain the structure, objectives and limitations of "funds form" that existed in modern form before the case of the cash flow statement in form of these days. Afterward, the theoretical discussions about cash flows and its role in the accounting theoretical framework are investigating. In the following, university's viewpoints and then the users' viewpoints of this information, in the area of the cash flows usefulness and at the end, previous internal and external research with reference to cash flows are discussed.

\subsection{The importance of predicting cash flows}

The forecasting of cash flow is significant that is needed in most of the economic decisions. Because cash flows play an important role approximately in all decisions of groups such as securities analysts, creditors and directors approximately. They are interested to assess the cash flows of future cash flow of company so as to achieve an observable indicator of cash flows of corporations in the future. In other words, a general purpose of fundamental analysis is the forecasting future cash flows of corporations' future (Staubus, 2004). Because paying dividend, interest and repaying liabilities are based on the cash flows. In decisions associated to investment in securities, investors or financial analysts need to estimate the cash return from investment in capital market. Cash return included cash from the dividends or increasing in value of the shares when they are sold. The ability of a corporation in paying dividends is resulted from its ability in creating future cash flows. Accordingly, in decisions with regard to making investments, forecasting cash flows of a company that is distributed as dividend, is the primary and main function in exhibiting ability of company in paying dividend for future periods (Neill, Schaefer, Bahnson, \& Bradbury, 1991). In decisions related to creditors for paying loans to the company, forecasting issues related to bankruptcy of customers could help them to prevent the occurrence of losses that might create due to paying loans which their repayment of them are not likely to be recovered or might not recoverable. There are several symbol and sign of danger that indicate a company has been faced to the situations and conditions of the bankruptcy. Cash flows are one of the most important proxies for evaluating of the companies' financial problems. A decrease and deficiencies in cash flow is able to pronounce a danger of bankruptcy for creditors and other 


\section{Mll Macrothink}

International Journal of Accounting and Financial Reporting ISSN 2162-3082 2013, Vol. 3, No. 1

groups who have benefits in the company (Zwaig \& Pickett, 2001). From the management's viewpoint of company, the cash flow is taken into account as a vital power for the company so that whenever the company needs cash, the needed cash must be financed. Consequently, the company ability in creating and cash management is important for the remaining and lasting its life (Sharma, 2001). Forecasting future cash flows makes company powerful by means of which company would be able to identify its cash position and according to that, issue the certificate of the repayment of liabilities or payment of some capital expenditures (Plewa Jr \& Friedlob, 1995). Additionally, it should be analyzed the difference between real cash flows with what has been forecasted in order to be evaluated the performance of the companies. Investment on fixed assets and capital budgeting analysis needs predicting cash flows. Capital budgeting is involved in investment projects such as new products, existing assets replacement or expansion of existing production lines (Bierman, 1988). These projects are assessed by using methods such as net present value and internal rate of return. In assessing projects, managers or analysts need to estimate the amount needed to do investments and also annual operational cash flows that has been estimated after the implementation of the project in estimated financial periods that is created for those projects. Then a manager must decide whether projects will be accepted or rejected based on assumptions of every method. As an example, according to net present value method, a project is accepted when present value of operational cash flows result from project is more than primary investment cost. Or in other words, net present value of its cash flows is positive (Brigham \& Gapenski, 1999). The importance of forecasting cash flows is considered by accounting statements. Financial Accounting Standards Board (FASB) and also International Accounting Standards Committee (IASC) have submitted strategic guidance for preparing and presenting financial statements and have stated that the aim of financial statements reporting is to provide financial information for users to help them in the direction of forecasting amount, timing and uncertainty related to company future cash flows. The aim of presenting the accounting data is providing information to help potential and present invertors, creditors and others to assess the amount, timing, and uncertainty associated to net input cash flows related to the company (FASB, 1984). Information about economic sources under control and capacity of company for adjusting these sources are useful in predicting ability of the company to create cash and cash equivalents in the future useful (IASC, 1992).

\section{Literature review}

Aghaei \& Shakeri (2010) studied the cash flow ability and earnings accruals components in forecasting cash flow of accepted companies in Tehran Stock Exchange over the period between 2003 till 2007. The results showed that earnings, cash flow, accrual components and cash flow have predictive ability of future cash flow. Also, cash flow model, model of cash flow and accruals components have better predictive ability than earnings model. Moreover, the results show that liquidity ratios don not has predictive ability of future cash flows. Pourheydari et al. (2009) studied the predictive ability of information with regard to statement of cash flows in direct and indirect methods. The results of the study showed that presenting information as to cash flows from operational activities in direct method in comparison to indirect method have more ability to predict future cash flows. Mirfakhraldini 


\section{Mll Macrothink}

International Journal of Accounting and Financial Reporting ISSN 2162-3082 2013, Vol. 3, No. 1

et al. (2009) predicted future cash flow through establishing three models of earnings, cash flows, cash flows and earnings accruals components. 73 accepted companies in Tehran Stock Exchange were investigated over the period of time from 1380 to 1385 years in the research. The results indicated that earnings, cash flows, cash flows and earnings accruals components, have predictive ability of the future cash flows, but there is no difference among three predicting models. Etemadi and Tariverdi (2006) conducted a post-test plan of multiple groups in order to determine the effects of methods presenting statement of cash flows on professional investors' judgments. The results indicated that methods of presenting statement of cash flows effect on professional investors' judgments. While Saghafi and Hashemi (2005) investigating the relationship between operational cash flows and accruals, they have presented a model for predicting operating cash flows. The research was conducted using data concerning 71 accepted companies in Tehran Stock Exchange over the period 1374 to 1382. The results of the research showed that there is a meaningful relationship between operational cash flows and accounting earnings and its components. Janatrostam (1999) investigated the earnings role in forecasting cash flows and future earnings. The sample of this research was 51 accepted companies in Tehran Stock Exchange and its investigation method was based on research conducted by Finger (1994). After testing the assumption, the researcher found that: 1) Historical earnings' are as a good predictor for future earnings for 92.16 per cent of the selected companies. 2) Historical earnings' are as a good predictor for future cash flows for 82.24 per cent of the selected companies. 3) Earnings and historical cash flows are as good predictor for future cash flows for 82.35 per cent of the selected companies. 4) Earnings versus cash flow do not have much superiority in forecasting future cash flows. Farshadfar et al. (2008) examined the earnings relative ability and cash flows in forecasting future cash flows. The results show that operating cash has more power in comparison with earnings and cash has been calculated through traditional methods in forecasting future cash. In addition, its profit predictability and operational cash flows increased considerably as much as the company size increase. Also, in parallel with the increase in the company size, the superiority of operating cash flow in comparison to earnings in forecasting operating cash flows gets more power. Yodar (2006) investigated ability of accruals models in relation to cash models in order to forecast the future cash flows. The researcher found that accrual models in comparison with cash flows model did not have increasing ability for forecasting future year cash. Barth et al. (2001) expand the model of the Dechow et al. (1998) in order to investigate the role of the accruals in predicting future cash flows, with the use of analyzing earnings into cash flows and accruals (the change in receivable accounts, the change in payable accounts, the change in inventory, depreciation and other accruals). The results showed that each of the accruals items reflects different information related to the future cash flows. In addition, results implicitly point out that the current earnings alone, and accruals items in the current year have less predictive ability than cash flows alone. Clinch et al. (2002) investigated usefulness of the components of the operational cash flows in predicting future operational cash flows. The results showed that explanation ability of operational cash flow components (cash received from customers in relation with sale, cash paid to Sellers for buying, payment of interest, dividends ...) is more in comparison with the total operational cash flows. In other words, operational cash flows 
components have increasing ability so as to predicting future operational cash flows (next year). Quirin et al. (1999) investigated four different predictors of operational cash flow including net earnings before extraordinary items, net earnings plus depreciation, working capital from operation and real cash flows from operation. They investigated 1442 observations related to the companies from 1996 to 1988 by means of least squares regression in their analysis. The results of four models were contradictory and uncoordinated for every year. Real cash flows $\mathrm{h}$ from operations was the best future cash flow predictor in 5 years out of the 8 years. Working capital from operations in comparison with others was the best predictor in 1989 and 1990. Even though, net earnings plus depreciation had the most predictive ability in 1996. Net earnings before extraordinary was not a preferential predictor in the whole 8 years. The results of the integrating and accumulating of the samples showed that real cash flows from operations for the entire period of 1996 to 1989 were the best predictor. Subsequently, operational working capital, net earnings plus depreciation and net earnings before extraordinary were the best respectively. The research concluded that earnings calculated based on accruals in comparison with cash flows based on cash basis have less predictive ability. The relationship between earnings and cash flows with regard to accepted companies in New Zealand Stock Exchange during period from 1992 to 1989 were examined by Seng (2006). This research which was based on the research Bowen et al. (1986), investigated the ability of the earnings and cash flows different classes (e.g. operational, investment and finance) in predicting cash flows in next period one or two. The results of the research were as follows: a) Operational cash flows in comparison with an interest are better predictors of operational cash flows one and two next periods. b) Cash flows from investment activities in comparison with earnings are better predictors of investment cash flows one and two next periods. c) Cash flows from finance activities in comparison with earnings are better predictors of finance cash flows one and two next periods. Although the correlation results indicate that cash flow traditional measures (operational working capital and earnings plus depreciation) have a high correlation with earnings however this correlation among these own measures is low. Finger (1994) used time series model so as to test the predicting ability of company particular future cash flows for the whole period by use of annual data related to 50 companies from 1935 to 1987. In this research also cash flow from operations has been calculated approximately through adjusting earnings before extraordinary, accrued tax, the changes in current assets and current liabilities with the exemption of current portion of long liabilities. Earnings in the form of net earnings before extraordinary which is derived from the income statement has been used in the research. Finger indicated that earnings which are used whether alone or along with cash flows are an important predictor for the future cash flows. Although the achieved results determined that current cash flows for predicting short period, are better predictors than the current earnings. Arnold et al. (1991) dealt with the study of the relationship between earnings and different measures of cash flow. Based on an annual data of 171 companies in London Stock Exchange during period 1984 to 1965, the researchers recognize: a) there is a relationship between earnings and working capital from operations for many companies; while association between earnings and other variables of cash flow is not considerable for many companies. b) Although use of the accounting based on accrual is useful in predicting 


\section{MInstitute Macrothink $^{m}$}

International Journal of Accounting and Financial Reporting ISSN 2162-3082 2013, Vol. 3, No. 1

future cash flows, but this study did not reach any evidence indicating superiority accounting earnings in comparison with historical cash flows to predict future cash flows. Murdoch and Krause (1990) put forward three questions: a) Whether a current year earnings is a better predictor for future cash flows from operations or current cash flows from operations? b) Whether earnings current factors are more importance in predicting future cash flows from operations or its noncurrent factors? c) Whether using earnings or cash flow data provide a more accurate predictor of future cash flows in long term periods or in short term periods? Their research emphasized on the percentage of changes in return of annual cash flow. Net earnings, capital working from operations and operational cash flow were main variables. Cash flows from operations and working capital had been calculated by adjusting net earnings. They applied data regarding 20 years from 1985-1966. With regard to the first question, The results of the study has supported the claim of Financial Accounting Standards Board that has dealt with earnings in comparison with cash flows from operations is a better predictor. In response to the second question, they realized that the earnings current factors that have been applied in measuring working capital are better predictor compared with noncurrent factors that has been applied in measuring earnings. In other words, working capital from operations is better than earnings. In response to third question, they realized that the accuracy of model prediction is increased through long-term data. Greenberg et al. (1986) experimented whether current earnings are better predictor for the future cash flows or current cash flows. They sampled 157 industrial companies for the period from 1963 to 1982. Used operating cash flow variable in this investigation indirectly and by using adjusting earnings had been calculated for non-cash items and changes in the current assets and liabilities. The mean of the linear relationship between current cash flow of every company and its past cash flows and also the mean of the linear relationship between current cash flows every company and its past earnings, had calculated with the use of least squares regression. Their results showed that current earnings compared with current cash flows have better ability to predict future cash flows. Brooks (1981) with the use of time series analysis put forward this issue that whether adding earnings information to historical cash flows compared with using historical cash flows causes improvement in predicting future cash flows or not. Based upon seasonal data for 30 companies, Brooks was unable to achieve improvement considerably in forecasting future cash flows with adding time series information.

\section{Research Methodology}

This research is going to investigate the extent of the earnings ability and operational cash flows in predicting future cash flows as main objective of research and also earnings ability plus depreciation and operational working capital in predicting future cash flows as research secondary objective and to answer this question that which of the variables of earnings, operational cash flows, earnings plus depreciation and operational working capital, have more capacity for future cash flows. From the viewpoint of the statistical analysis, the research uses panel data regression model using data year-company and ordinary least squares (OLS) method. Present research statistics population is all the companies accepted in Tehran stock exchange. This research includes the companies of the stock exchange that are 


\section{Al Macrothink}

International Journal of Accounting and Financial Reporting

ISSN 2162-3082

2013, Vol. 3, No. 1

selected with the following preferences: a) Companies must be a member of companies listed in Tehran stock exchange. b) In order to consider comparability, companies' fiscal year should be end on March $19^{\text {th }}$ every year and did not change during period from 2005 to 2009. c) Banks and investment companies are not investigated in this research study based on the nature of their assets. Considering the limitations above, the number of 94 companies consisted statistical population that due to a limited number of companies, all of the 94 companies were investigated.

\subsection{Research variables}

Cash flow from operating (CFO): Operating activities is composed of main activities of business entity's revenue productive. These operations require production and sell goods and render service and expenses, revenues relating to those are considered in determination of operational income or loss in income statement. Cash flows from operational activities are basically consisting cash inflows and outflows with regard to mentioned operations that it is the latest figure reported in the section of cash flows from operating activities in cash flow statement.

Earnings (EARNS): Net earnings after tax but before extraordinary items (reported in income statement)

Net earnings plus depreciation expense (EDPR): One of the traditional measures is cash flow that is calculated with adding period depreciation expense (tangible and intangible assets) to net earnings before extraordinary items.

Working capital from operations (WCFO): Working capital from operations (WCFO) is the second traditional measure of cash flow that is calculated as following:

Operational cash flows $=$ change in current assets with the exception of cash - change in current liabilities

\subsection{Research hypothesis}

$H_{1:}$ operational cash flows have ability to predict future cash flows.

$H_{2:}$ current earnings have ability to predict future cash flows.

$H_{3:}$ current earnings plus depreciation have ability to predict future cash flows.

$H_{4:}$ operational working capital has ability to predict future cash flows.

\subsection{Empirical model to measure cash flow from operating}

We estimate the following model explaining cash flow from operating in year $t$, incorporating the three primary variables of earnings, net earnings plus depreciation expense, working capital from operation, and cash flow from operating in year $t$ - 1 , initially using OLS regression analysis

$$
C F O_{i t}=\alpha_{0}+\alpha_{1} E A R N S_{i t-1}+\beta_{1} E_{D P R_{i t-1}}+\gamma_{1} W C F O_{i t-1}+\delta_{1} C F O_{i t-1}+\varepsilon_{i t}
$$




\section{Results}

Table 1. Descriptive statistics

\begin{tabular}{lccccc}
\hline & CFO t & CFO t -1 & EARNS t -1 & EDPR t - & WCFOt-1 \\
\hline Mean & 0.1781 & 0.1448 & 0.1725 & 0.1965 & 0.1580 \\
Median & 0.1417 & 0.1265 & 0.1323 & 0.1543 & 0.1306 \\
Maximum & 1.0431 & 0.7725 & 0.9065 & 0.8472 & 1.3150 \\
Minimum & -0.6403 & -0.5321 & -0.1593 & -0.1251 & -0.525 \\
Std. Dev. & 0.2058 & 0.1757 & 0.1639 & 0.1662 & 0.2419 \\
Skewness & 0.7429 & 0.4103 & 1.3481 & 1.3064 & 1.0596 \\
Kurtosis & 5.3995 & 4.9283 & 5.2706 & 5.0234 & 6.7752 \\
Jarque-Bera & 155.99 & 86.010 & 243.32 & 213.88 & 367.06 \\
Probability & 0.0000 & 0.0000 & 0.0000 & 0.0000 & 0.0000 \\
Sum & 83.744 & 68.063 & 81.081 & 92.383 & 74.283 \\
Sum Sq. Dev. & 19.865 & 14.482 & 12.601 & 12.968 & 27.460 \\
\hline Observations & 470 & 470 & 470 & 470 & 470 \\
\hline
\end{tabular}

\subsection{The results and analysis at the level of companies}

Table 2. Results of regression models investigation in the level of total companies

\begin{tabular}{lcccc}
\hline & Model 1 & Model 2 & Model 3 & Model 4 \\
\hline CFO & 0.7808 & & & \\
& $(17.3472)$ & & & \\
EARNINGS & & 0.6729 & & \\
& & $(6.4978)$ & 0.6631 & \\
EDPRT & & & $(6.8458)$ & \\
& & & & 0.3140 \\
WCFO & & & 0.3406 & 0.2389 \\
& & & 2.01842 & 2.0598 \\
Adjusted R & & & & \\
Durbin-Watson & 0.3119 & 0.3422 & 121.919 & 74.4862 \\
F-statistic & 2.0031 & 2.0200 & 0.0000 & 0.0000 \\
Prob (F-statistic) & 107.08 & 122.77 & & \\
\hline
\end{tabular}

Table 2 shows the first four models in the level of total companies. With regard to the output of the Eviews in above table:

Current operational cash flow variable has a positive and meaningful relationship with dependent variable at level of 95 percent. Also, according to the $F$ statistics probable, 


\section{Macrothink}

International Journal of Accounting and Financial Reporting ISSN 2162-3082 2013, Vol. 3, No. 1

regression equation is not rejected in general. Adjusted $R^{2}$ coefficient is 31 percent. Durbin-Watson is 2 that point out the lack of the autocorrelation. Current earnings variable at the level of confidence 95 percent has a positive and meaningful relationship with dependent variable. Also, regression equation is not rejected in general in accordance with $F$ statistics probable. Coefficient of adjusted $R^{2}$ is 34 percent. Durbin-Watson is 2.02 that indicate the lack of the autocorrelation. Earnings variable plus depreciation expense has a meaningful and positive relationship with dependent variable at the level of 95 percent of confidence. Also, regression equation is not rejected in general consistent with $F$ statistics probable. Coefficient of adjusted $R^{2}$ is 34 percent. Durbin-Watson is 2.01 that highlight the lack of the autocorrelation. Operational working capital variable has a meaningful and positive relationship with dependent variable at the level of 95 percent of confidence. Also, regression equation is not rejected in general corresponding to $\mathrm{F}$ statistics probable. Coefficient of adjusted $R^{2}$ is 23.8 percent. Durbin-Watson is 2.05 that indicate the lack of the autocorrelation.

\section{2 General regression model test (pooled model) for total companies}

Since we deal with several independent variables in the panel data model, at the first we must investigate the collinearly between independent variables. For this purpose, we first have used collinearly test of VIF (Variance Inflation Factor) that its results are in the following table:

Table 3. Results of Variance inflation Factor (VIF) collinearly test

\begin{tabular}{lccccc}
\hline Predictor & Coef & SE Coef & T & P & VIF \\
\hline Constant & 0.0345 & 0.0122 & 2.81 & 0.005 & \\
CFO $_{t-1}$ & 0.3468 & 0.0660 & 5.25 & 0.000 & 2.482 \\
EARNS $_{\mathrm{t}-1}$ & 0.3453 & 0.2341 & 1.48 & 0.141 & 27.138 \\
EDPR $_{\mathrm{t}-1}$ & 0.1477 & 0.2329 & 0.63 & 0.526 & 27.636 \\
WCFO $_{\mathrm{t}-1}$ & 0.0301 & 0.0482 & 0.63 & 0.532 & 2.512 \\
\hline
\end{tabular}

Since the VIF statistic is more than 10 for the two variables current earnings and current earnings plus depreciation expense variable, therefore there is a critical collinearly problem and one of the variables must be excluded from the regression model. For this purpose, once we exclude earnings variable and once again earnings plus depreciation expense from the model. Then again, we do the goodness-of-fit of regression equation. The results and output of Eviews for the model (5-1) and model (5-2) are comparing in the following table: 
Table 4. Results of general regression model (pooled model) for total companies

\begin{tabular}{lcc}
\hline & model 5-1 & model 5-2 \\
\hline CFO & 0.4744 & 0.4781 \\
& $(3.7717)^{*}$ & $(3.7849)^{*}$ \\
EARNINGS & & 0.4490 \\
& & $(3.5445)^{*}$ \\
EDPRT & 0.4437 & \\
WCFO & $(3.6315)^{*}$ & \\
\hline Adjusted R & 0.0138 & 0.0148 \\
Durbin-Watson & $(0.2058)^{* *}$ & $(0.2146)^{* *}$ \\
F-statistic & 0.4079 & 0.4101 \\
Prob(F-statistic) & 2.0049 & 2.0054 \\
\hline
\end{tabular}

*indicates significance at level of 99 percent of confidence.

** indicates a lack of significance.

With regard to output of Eviews in the above table, Current cash flow variable and current earnings plus depreciation expense have a meaningful and positive relationship with dependent variable at the level of 95 percent of confidence. Also, Coefficient of adjusted $R^{2}$ is 40 percent. Durbin-Watson is 2 that indicate the lack of the autocorrelation. Besides, regression equation (model 5-1) is meaningful generally consistent to F statistics probable. Current cash flow variable and current earnings have a meaningful and positive relationship with dependent variable at the level of 95 percent of confidence. Moreover, Coefficient of adjusted $R^{2}$ is 41 percent. Durbin-Watson is 2 that point out the lack of the autocorrelation. In addition, regression equation (model 5-1) is generally meaningful consistent to $\mathrm{F}$ statistics probable. For the meantime, as you see, regression coefficient for the WCFO variable is insignificance in both models.

\section{Conclusion}

Forecasting operational cash flows is meaningfully possible using past years operational cash flows. In other words, the first hypothesis is confirmed at the level of 95 percent. From this perspective, the result of this study is consistent with the result of the studies carried out by Brooks (1981), Bowen et al. (1986), Percy and Stokes (1992), Seng (2006), Quirin et al. (1999), Krishnan and Largay (2000), Barth et al. (2001), Al- Attar and Hussain (2004), Kim and Kross (2005). Predicting operating cash flows with the use of historical earnings is possible significantly. It means that the second hypothesis is confirmed at the level of 95 percent of confidence which from this view, the result of this research is consistent with the results of the studies carried out by Greenberg et al. (1986), Dechow et al. (1998), Murdoch and Krause (1990), Lorek and Willinger (1996), Barth et al. (2001). Forecasting operational 


\section{MInstitute Mach $^{m}$}

International Journal of Accounting and Financial Reporting ISSN 2162-3082 2013, Vol. 3, No. 1

cash using the first traditional measure of cash flow namely earnings plus depreciation is probable meaningfully. In other words, this hypothesis is confirmed at the level of 95 percent confidence. From this viewpoint, the result of this research is consistent with result of the research carried out by Percy and Stokes (1992). The second traditional criteria of cash flow, operational working capital is able to predict operational cash flows meaningfully. Therefore, the fourth hypothesis is confirmed at the level of 95 percent of confidence. From this view, the result of this study is consistent with the studies conducted by Murdoch and Krause (1990), and Percy and Stokes (1992). As the results show, with regard to the comparison of the models from the viewpoint of predictability, historical earnings compared to operational cash flows, have more capability in predicting future cash flows. This finding is consistent with the asserted by Financial Accounting Standards Board (FASB) and also the results of the researches conducted by Greenberg et al. (1986), Dechow et al. (1998), Murdoch and Krause (1990), Lorek and Willinger (1996), Barth et al. (2001). According to the result of this study, in the area of predictive capacity after earnings are, the first traditional measure of cash flow namely net earnings plus depreciation expense, operating cash flow, and operating working capital respectively. Also, according to the result of this study, using historical operating cash flows and historical earnings and operating working capital simultaneously (general model in the first case) and also, using operating cash flows simultaneously, earnings plus depreciation and operational working capital (general model in the second case) prediction model is improved to a great extent compared to using only one of these variables. The results of this investigation are consistent with the studied by Barth et al. (2001) and Al-Attar and Hussein (2004). Of course, it should be added that according to the results, these two pooled models have no much difference with each other from the viewpoint of predictive ability.

\section{References}

Aghaei, M., \& Shakeri, A. (2010). Application Cash Flow Ratios, Cash Flows and Accrual Accounting in Predicting Future Operating Cash Flow in Listed Companies of Tehran Stock Exchange. Financial Accounting, 2(5), 1-16.

Al-Attar, A., \& Hussain, S. (2004). Corporate data and future cash flows. Journal of Business Finance \& Accounting, 31(7\&8), 861-903.

Arnold, A. J., Clubb, C., Manson, S., \& Wearing, R. (1991). The relationship between earnings, funds flows and cash flows: evidence for the UK. Accounting and Business Research, 22(85), 13-19.

Barth, M. E., Cram, D. P., \& Nelson, K. K. (2001). Accruals and the prediction of future cash flows. The Accounting Review, 76(1), 27-58.

Bierman, H. (1988). Extending the Usefulness of Accrual Accounting. Accounting Horizons, $2,10-14$.

Bowen, R. M., Burgstahler, D., \& Daley, L. A. (1986). Evidence on the relationships between earnings and various measures of cash flow. The Accounting Review, 61, 713-725.

Brigham, E., \& Gapenski, L. C. (1999). International financial management: The Dryden 
Press, Orlando, Fla.

Brooks, J. E. (1981). An Empirical investigation of the usefulness of earnings in predicting future enterprise cash flows. Working Paper, Michigan State University.

Clinch, G., Sidhu, B., \& Sin, S. (2002). The usefulness of direct and indirect cash flow disclosures. Review of Accounting Studies, 7(4), 383-404.

Dechow, P. M., Kothari, S., \& L Watts, R. (1998). The relation between earnings and cash flows. Journal of Accounting and Economics, 25(2), 133-168.

Etemadi, H., \& Tariverdi, Y. (2006). The Impact of Various Models of the Statement of Cash Flows on Professional Investors' Judgments. The Iranian Accounting and Auditing Review, 45(13), 69-88.

Farshadfar, S., Ng, C., \& Brimble, M. (2008). The relative ability of earnings and cash flow data in forecasting future cash flows: Some Australian evidence. Pacific Accounting Review, 20(3), 254-268.

FASB (1984). Recognition and Measurement in Financial Statement of Business Enterprises. Concepts Statement No. 5 Financial Accounting Standard Board

Finger, C. A. (1994). The ability of earnings to predict future earnings and cash flow. Journal of Accounting Research, 210-223.

Greenberg, R. R., Johnson, G. L., \& Ramesh, K. (1986). Earnings versus cash flow as a predictor of future cash flow measures. Journal of Accounting, Auditing \& Finance, 1(4), 266-277.

IASC (1992). Statement of Cash Flow IAS 7, International Accounting Standards Committee.

Janatrostami, M. T. (1999). The Review of Role and Predictability Earnings in Predicting Earnings and Future Cash Flows of Investment in Listed Companies in Tehran Stock Exchange Department of Management and Accounting, Shahid Beheshti University, Unpublished M. A., Dissertation

Kim, M., \& Kross, W. (2005). The ability of earnings to predict future operating cash flows has been increasing-not decreasing. Journal of Accounting Research, 43(5), 753-780.

Krishnan, G. V., \& Largay III, J. A. (2000). The predictive ability of direct method cash flow information. Journal of Business Finance \& Accounting, 27(1\&2), 215-245.

Lorek, K. S., \& Willinger, G. L. (1996). A multivariate time-series prediction model for cash-flow data. Accounting Review, 71, 81-102.

Mirfakhraldini, S. H., Moeinaldin, M., \& Ebrahimpour, A. R. (2009). Comparing the Power of Chas Flows and Accruals in Predicting furture Cash Flows. The Iranian Accounting and Auditing Review 55, 99-116.

Murdoch, B., \& Krause, P. (1990). Further evidence on the comparative ability of accounting data to predict operating cash flows. The Mid-Atlantic Journal of Business, 26(2), 1-14. 


\section{Macrothink}

International Journal of Accounting and Financial Reporting

ISSN 2162-3082

Neill, J. D., Schaefer, T. F., Bahnson, P. R., \& Bradbury, M. E. (1991). The usefulness of cash flow data: A review and synthesis. Journal of Accounting Literature, 10, 117-150.

Percy, M., \& Stokes, D. J. (1992). Further evidence on empirical relationships between earnings and cash flows. Accounting \& Finance, 32(1), 27-49.

Plewa Jr, F. J., \& Friedlob, G. T. (1995). Understanding cash flow: Wiley.

Pourheydari, O., Nazemi Ardakani, M., \& Mohammadi, A. (2009). A Comparative Review of Predictive Ability of Direct and Indirect Methods Cash Flow Information. The Iranian Accounting and Auditing Review, 16(57).

Quirin, J. J., O'Bryan, D., Wilcox, W. E., \& Berry, K. T. (1999). Forecasting cash flow from operations: Additional evidence. Midatlantic Journal of Business, 35, 135-142.

Saghafi, A., \& Hashemi, A. (2005). Analytical Review of Association between Accruals and Operating Cash Flows: A Model for Predicting Cash Flow. The Iranian Accounting and Auditing Review, 38, 29-52.

Seng, D. (2006). Earnings versus cash flows as predictors of future cash flows: New Zealand evidence. working paper, University of Otago.

Sharma, D. S. (2001). The role of cash flow information in predicting corporate failure: The state of the literature. Managerial Finance, 27(4), 3-28.

Staubus, G. J. (2004). Two views of accounting measurement. Abacus, 40(3), 265-279.

Yoder, T. R. (2006). The incremental cash flow predictive ability of accrual models. The Pennsylvania State University.

Zwaig, M., \& Pickett, M. (2001). Loss Prevention Early Warning Signs of a Bankruptcy. Business Credit New York, 103(1), 65-65. 